\title{
Serotonin 1A Receptors, Serotonin Transporter Binding and Serotonin Transporter mRNA Expression in the Brainstem of Depressed Suicide Victims
}

Victoria Arango, Ph.D., Mark D. Underwood, Ph.D., Maura Boldrini, M.D., Hadassah Tamir, Ph.D., Suham A. Kassir, B.A., Shu-chi Hsiung, M.S., Jason J.-X. Chen, M.D., Ph.D., and J. John Mann, M.D.

Suicide and depression are associated with reduced serotonergic neurotransmission. In suicides, there is a reduction in serotonin transporter (SERT) sites and an increase in postsynaptic $5-H T_{1 A}$ receptors in localized regions of the prefrontal cortex. In depression, there is a diffuse decrease in SERT binding throughout the dorsoventral extent of the prefrontal cortex. Serotonergic innervation of the prefrontal cortex arises predominantly from neurons in the brainstem dorsal raphe nucleus (DRN). We, therefore, examined postmortem SERT binding and $m R N A$ expression, as well as $5-H T_{1 A}$ autoreceptor binding in the DRN of 10 matched pairs of controls and depressed suicide victims. The concentration of SERT sites, SERT $m R N A$, and $5-H T_{1 A}$ binding was not different between controls and suicides ( $\mathrm{p}>.05)$. In the DRN of suicides, the volume of tissue defined by $5-\mathrm{HT}_{1 A}$ binding was $40 \%$ smaller than controls. An index of the total number of $5-\mathrm{HT}_{1 A}$ receptors (receptor binding $\times$ volume of receptor distribution) was $43.3 \%$ lower in the DRN of suicides, compared with controls. The suicide group had $54 \%$ fewer DRN neurons expressing SERT mRNA compared with controls. In the serotonin neurons that expressed the SERT gene, expression per neuron was greater in suicides. Less total $5-H T_{1 A}$ and SERT binding is consistent with results of in vivo studies in depression. Less feedback inhibition of serotonin DRN firing via $5-H T_{1 A}$ autoreceptors and enhancement of serotonin action due to less uptake of serotonin, is consistent with compensatory changes in response to hypofunction in depressed suicides.

[Neuropsychopharmacology 25:892-903, 2001] (C) 2001 American College of Neuropsychopharmacology. Published by Elsevier Science Inc.
From the Department of Neuroscience, New York State Psychiatric Institute, New York, NY (VA, MDU, MB, HT, SAK, S-cH, JJM); Department of Psychiatry (VA, MDU, MB, HT, JJM) and Department of Anatomy and Cell Biology (VA, HT, JJ-XC), Columbia University College of Physicians \& Surgeons, New York, NY.

Address correspondence to: Victoria Arango, Ph.D., Department of Neuroscience, New York State Psychiatric Institute, 1051 Riverside Drive, Box 42, New York, NY 10032.

Received 17 August 2000; revised 18 May 2001; accepted 26 July 2001.

Online publication: 6/29/01 at www.acnp.org/citations/ Npp062901142.
KEY WORDS: Dorsal raphe nucleus; Postmortem; In situ hybridization; Receptor autoradiography

Reduced serotonergic function in the brain of suicide victims is suggested based on findings of lower brainstem levels of serotonin (5-HT) and 5-hydroxyindoleacetic acid (5-HIAA), as well as fewer serotonin transporter (SERT) binding sites and more post-synaptic $5-\mathrm{HT}_{1 \mathrm{~A}}$ receptors in prefrontal cortex in suicide victims (see Mann et al. 2000 for review). In suicide victims, the changes in SERT and $5-\mathrm{HT}_{1 \mathrm{~A}}$ binding are 
localized to the ventral PFC (Arango et al. 1995), an area involved in behavioral inhibition (Damasio et al. 1994) and, therefore, the potential location of a diathesis for suicidal behavior.

Studies in depressed suicide attempters compared to psychiatric controls have found lower cerebrospinal levels of 5-HIAA (Mann and Malone 1997). In vivo studies have employed pharmacological challenges that activate brain serotonin receptors invoking release of prolactin that can be measured in the blood (Mann et al. 1995; Malone et al. 1996) or a change in regional glucose metabolism in the brain that can be measured by positron emission tomography (Malone et al. 2000). Results of these studies indicate blunted responses to 5-HT and support the notion of serotonin deficiency in depressed suicidal patients. Importantly, the relationship of serotonin hypofunction to suicidal acts is independent of psychiatric diagnosis (Mann et al. 1989; Stanley et al. 2000; Coccaro et al. 1989).

The most widely reported serotonergic abnormality in major depression involves fewer platelet serotonin transporter sites (Owens and Nemeroff 1994). In vivo imaging (Malison et al. 1998; Willeit et al. 2000) and postmortem brain studies (Perry et al. 1983; Arango et al. 1995; Mann et al. 2000) conducted in depressed patients suggest that less SERT binding is more widespread in the brain compared with suicides, and includes the brainstem. One potential cause for fewer SERT sites, in the prefrontal cortex and elsewhere, would be a reduction in SERT gene expression. SERT mRNA is expressed in 5-HT neurons in the brainstem.

We previously reported (Austin et al. 1994) the first anatomical visualization of human brain serotonin transporter gene expression and described the localization of the SERT mRNA to the serotonergic neurons of the dorsal raphe nucleus (DRN) and median raphe nucleus (MRN). In rodents, non-human primates, and presumably humans, it is the dorsal and median raphe nuclei that provide the serotonergic innervation of the entire forebrain (Wilson and Molliver 1991a,b; Bobillier et al. 1975, 1976; Sakai et al. 1977).

In the $\mathrm{DRN}$, the $5-\mathrm{HT}_{1 \mathrm{~A}}$ receptor is a somatodendritic inhibitory autoreceptor on 5-HT neurons (Vergé et al. 1985; Middlemiss and Fozard 1983). 5-HT released locally acts on the autoreceptor to inhibit further release of the 5-HT transmitter (Wang and Aghajanian 1977). Altered autoinhibition at the $5-\mathrm{HT}_{1 \mathrm{~A}}$ receptor in the brainstem raphe nuclei might be a mechanism that contributes to reduced serotonergic neurotransmission in prefrontal cortex in suicide and depression (Stockmeier et al. 1998). In vivo studies report lower brainstem $5-\mathrm{HT}_{1 \mathrm{~A}}$ binding in depression (Drevets et al. 1999; Sargent et al. 2000), an effect that would tend to enhance serotonergic activity and potentially a homeostatic mechanism.

We sought to determine in 10 matched pairs of controls and depressed suicide victims whether: 1) SERT binding is reduced in the dorsal raphe nucleus; 2) alterations in SERT sites are associated with altered expression of SERT mRNA; and 3) $5-\mathrm{HT}_{1 \mathrm{~A}}$ autoreceptor binding is altered in the DRN. We have presented parts of these data in abstract form (Kassir et al. 1998).

\section{METHODS}

\section{Subjects}

Tissue was provided by the Allegheny County Coroner (Pennsylvania) or New York City Medical Examiner offices in accordance with city or county regulations and the Institutional Review Boards for Biomedical Research of the New York State Psychiatric Institute or the University of Pittsburgh approved the protocol. All cases died suddenly and had a postmortem delay of less than 24 hours. When required, next of kin consented to tissue collection and review of relevant records. With informed consent, at least one informant per case agreed to an interview for the purpose of a psychological autopsy, which was performed according to our previously reported method (Kelly and Mann 1996). Further details about the psychological autopsy procedure can be found in a recent publication (Mann et al. 2000).

Brains were collected at autopsy. The mesencephalon was detached from the diencephalon by a transverse cut rostral to the superior colliculi. A block approximately 1 inch in length, to the middle cerebellar pedunculi, was taken, flash-frozen in Freon $\left(-20^{\circ} \mathrm{C}\right)$ and stored at $-80^{\circ} \mathrm{C}$ until sectioning. Samples from the left cerebral hemisphere were fixed for neuropathological examination. Individuals with a history of cerebral trauma, central nervous system disease, chronic alcoholism, illicit or therapeutic drug use, or AIDS were excluded. Body fluids (blood, bile, aqueous humor, and urine) were used for toxicological screening for cocaine, opiates, alcohol, antidepressants, and other acidic and basic drugs.

Frozen sections (20 $\mu \mathrm{m}, n=700-1100)$ were serially cut in a cryostat (Hacker Bright) and thaw-mounted onto 2 " $\times 3$ ", acid-cleaned, gelatin-subbed glass slides. An intercalating set (every $200 \mu \mathrm{m}$ ) was stained for Nissl substance. Tissue sections were desiccated and stored in sealed boxes (at $-20^{\circ} \mathrm{C}$ for $24 \mathrm{~h}$, and $-80^{\circ} \mathrm{C}$ thereafter). The brain samples were coded and assayed by personnel blind to the cause of death. In order to ensure the integrity of the tissue for the in situ hybridization studies, we measured $\mathrm{pH}$ in the cerebellum as described by Harrison et al. (1995).

All the control subjects were psychiatrically normal. They were chosen as controls if they did not meet criteria for any Axis I diagnosis during their lifetime. Except for one control case and one suicide, all subjects had negative toxicological screens (Table 1). None of the 
Table 1. Demographics, Diagnoses, and Toxicology of Subjects in Study

\begin{tabular}{|c|c|c|c|c|c|c|c|c|c|c|}
\hline Pair No. & Class & Age, y & Sex & Race & PMI, h & MDE & Toxicology & Ethanol & Axis I Dx & Axis II Dx \\
\hline Pair 1 & $\mathrm{C}$ & 66 & Male & Caucasian & 19 & No & None & 0 & None & None \\
\hline Pair 1 & $S$ & 63 & Male & Hispanic & 17 & No & None & 0 & None & $\begin{array}{c}\text { Schizotypal } \\
\text { personality } \\
\text { disorder }\end{array}$ \\
\hline Pair 2 & $\mathrm{C}$ & 30 & Female & African American & 8 & No & None & 0 & None & None \\
\hline Pair 2 & S & 26 & Female & Hispanic & 18 & No & None & 0 & $\begin{array}{l}\text { Schizoaffective, } \\
\text { depressed phase }\end{array}$ & None \\
\hline Pair 3 & $\mathrm{C}$ & 40 & Female & Caucasian & 6.5 & No & None & 0 & None & None \\
\hline Pair 3 & $S$ & 34 & Female & Caucasian & 12.5 & Yes & None & 0 & MDD & None \\
\hline Pair 4 & $\mathrm{C}$ & 27 & Female & Caucasian & 15 & No & None & 0 & None & None \\
\hline Pair 4 & $S$ & 28 & Female & Caucasian & 19 & Yes & None & 0 & MDD, bulimia & None \\
\hline Pair 5 & C & 51 & Male & Hispanic & 7.5 & No & None & 0 & None & None \\
\hline Pair 5 & S & 66 & Male & Caucasian & 11 & Yes & None & 0 & MDD & None \\
\hline Pair 6 & $\mathrm{C}$ & 29 & Female & Caucasian & 16.5 & No & None & 0 & None & None \\
\hline Pair 6 & $S$ & 29 & Female & Asian & 4 & Yes & None & 0 & MDD & None \\
\hline Pair 7 & $\mathrm{C}$ & 36 & Male & Caucasian & 14 & No & Carbon monoxide & 0 & None & None \\
\hline Pair 7 & S & 31 & Male & Caucasian & 6 & Yes & Opiates & 0 & MDD & None \\
\hline Pair 8 & C & 53 & Male & Caucasian & 18.5 & No & None & 0 & None & None \\
\hline Pair 8 & $\mathrm{~S}$ & 50 & Male & Hispanic & 30 & Yes & None & 0 & MDD & None \\
\hline Pair 9 & $\mathrm{C}$ & 37 & Male & African American & 15 & No & None & 0 & None & None \\
\hline Pair 9 & $\mathrm{~S}$ & 40 & Male & Caucasian & 20 & Yes & Analgesic & 0 & MDD & None \\
\hline Pair 10 & $\mathrm{C}$ & 85 & Male & Caucasian & 7 & No & None & 0 & None & None \\
\hline Pair 10 & $S$ & 74 & Male & Caucasian & 21 & Yes & Opiates, analgesics & 0 & MDD & None \\
\hline
\end{tabular}

Abbreviations: C, control; S, suicide; PMI, postmortem interval; MDD, major depressive disorder.

suicides or controls met criteria for substance abuse during their lifetimes. It is notable that none of the depressed suicides had a psychotropic medication detected, consistent with previous reports that few suicides with major depression are taking antidepressants at the time of death (Isometsä et al. 1994). We did not take note of treatment history and assessed drug status purely on the basis of toxicology screens. Subjects were considered depressed if they had a diagnosis of major depression during their lifetime.

Subjects were matched in pairs for age (C: $45 \pm 19$ yrs vs. S: $44 \pm 18$ yrs), sex (C: six males: four females vs. S: six males: four females) and PMI (C: $12.7 \pm 4.9$ vs. S: $15.8 \pm 7.7$ h). Pair 1 was excluded from the in situ hybridization grain counting study because of a technical problem with the emulsion dipping.

\section{Brainstem}

We examined brainstem sections containing the DRN and MRN in suicide victims $(n=10)$ and normal controls $(n=10)$. Four sets of sections every $\mathrm{mm}$ were collected and assayed for: SERT mRNA by in situ hybridization (two slides), SERT sites (two slides), and 5- $\mathrm{HT}_{1 \mathrm{~A}}$ receptors (two slides) by quantitative receptor autoradiography (Figure 1), and stained for Nissl (one slide) for identification of neuronal elements using thionin.

Each slide used for receptor autoradiography was also stained with thionin and slides used for in situ hybridization were lightly stained with hematoxylin and eosin ( $\mathrm{H} \& \mathrm{E})$ to identify cellular elements without obscuring silver grains produced following emulsion dipping and development (Figure 2). The deep blue staining of rough endoplasmic reticulum, nucleoli and endothelial cell nuclei by thionin produces stained profiles that are problematic for the image analysis system to distinguish from silver grains.

\section{Quantitative Receptor Autoradiography of $\left[{ }^{3} \mathrm{H}\right] \mathrm{Cyanoimipramine}$ to the Serotonin Transporter (SERT) and $\left[{ }^{3} \mathrm{H}\right] 8-\mathrm{OH}-\mathrm{DPAT}$ to the 5- $\mathrm{HT}_{1 \mathrm{~A}}$ Autoreceptor}

Quantitative autoradiography of SERT sites was performed as previously described (Arango et al. 1995). Tissue sections were brought to room temperature in a vacuum-desiccator. After a 30-min preincubation (50 $\mathrm{mM}$ Tris- $\mathrm{HCl}[\mathrm{pH} 7.4], 120 \mathrm{mM} \mathrm{NaCl}, 5 \mathrm{mM} \mathrm{KCl})$ at $20^{\circ} \mathrm{C}$, sections were incubated in same buffer with 0.4 $\mathrm{nM}\left[{ }^{3} \mathrm{H}\right]$-cyanoimipramine (CN-IMI, $80 \mathrm{Ci} / \mathrm{mmol}$; American Radiolabeled Chemicals) and $30 \mu \mathrm{M}$ phenyl methyl sulfonyl fluoride for $20 \mathrm{~h}$ at $4^{\circ} \mathrm{C}$. Nonspecific binding was defined with $10 \mu \mathrm{M}$ sertraline.

Sections were washed in incubation buffer for $60 \mathrm{~min}$ at $4^{\circ} \mathrm{C}$. Autoradiography of $5-\mathrm{HT}_{1 \mathrm{~A}}$ sites was performed as previously described (Arango et al. 1995). Tissue sections were preincubated $\left(30 \mathrm{~min}, 22^{\circ} \mathrm{C}\right)$ in $170 \mathrm{mM}$ Tris$\mathrm{HCl}$ containing $4 \mathrm{mM} \mathrm{CaCl}$ and $138 \mathrm{mM}$ sucrose $(\mathrm{pH}$ 7.6). Incubations were carried out in the same buffer containing $2 \mathrm{nM}\left[{ }^{3} \mathrm{H}\right] 8 \mathrm{OH}-\mathrm{DPAT}$ and $0.01 \%$ ascorbic 


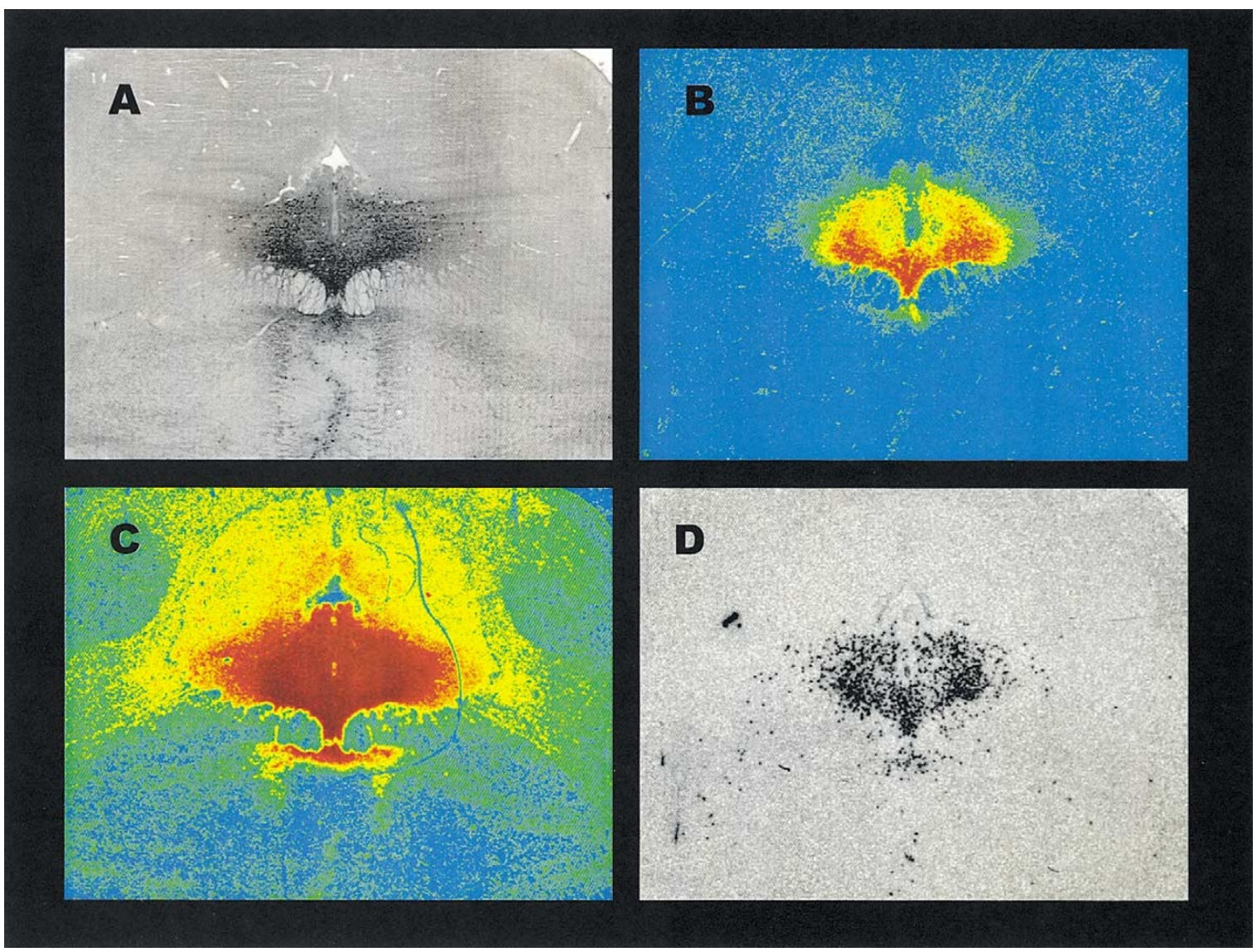

Figure 1. Representative near adjacent transverse sections through the rostral DRN. (A) Immunocytochemical localization of tryptophan hydroxylase (PH8); (B) Pseudocolor autoradiogram of [ $\left.{ }^{3} \mathrm{H}\right] 8-\mathrm{OH}-\mathrm{DPAT}$ to label 5- $\mathrm{HT}_{1 \mathrm{~A}}$ receptors; (C) Pseudocolor autoradiogram of $\left[{ }^{3} \mathrm{H}\right]$ Cyanoimipramine to label serotonin transporter (SERT) sites; and (D) in situ hybridization autoradiogram of SERT mRNA in the DRN. Note that there is a high degree of correspondence between the DRN as outlined by sections immunostained for tryptophan hydroxylase and sections labeled with $\left[{ }^{3} \mathrm{H}\right] 8-\mathrm{OH}-\mathrm{DPAT}$.

acid at $22^{\circ} \mathrm{C}$ for $60 \mathrm{~min}$. Parallel incubations containing $1 \mu \mathrm{M}$ 5-HT (oxalate salt) defined nonspecific binding, which was less than $10 \%$ of total binding. Sertraline (100 $\mathrm{nM}$ ) was added to incubations in order to mask binding to serotonin uptake sites. The addition of sertraline at this concentration did not affect binding to $5-\mathrm{HT}_{1 \mathrm{~A}}$ sites. Sections were washed for $10 \mathrm{~min}(2 \times 5$ min) in Tris- $\mathrm{HCl}$ buffer at $4^{\circ} \mathrm{C}$ and then, briefly, dipped in water, dried, and transferred to a vacuum desiccator until exposure.

Dried slides were arranged in x-ray film cassettes and exposed to tritium-sensitive film (Hyperfilm; Amersham, Uppsala, Sweden) for four weeks $\left(\left[{ }^{3} \mathrm{H}\right]-\mathrm{CN}\right.$ IMI) or two weeks $\left(\left[{ }^{3} \mathrm{H}\right] 8-\mathrm{OH}-\mathrm{DPAT}\right)$ with slidemounted tritium standards (American Radiolabeled Chemicals). The films were developed with D-19 (Eastman Kodak, Rochester, NY) for 4 min at $16^{\circ} \mathrm{C}$, rinsed briefly, and fixed (Kodak Rapid Fixer) for $10 \mathrm{~min}$. The tissue sections were fixed in 10\% buffered formalin and stained for Nissl substance with thionin.

\section{In Situ Hybridization Histochemistry of SERT mRNA}

The sequence of the antisense oligonucleotide probe was designed to exhibit significant divergence with other monoamine transporters. A new oligonucleotide corresponding to bases 1667-1710 of the human 5-HT transporter cDNA (Lesch et al. 1993) was synthesized by GibcoBRL (Grand Island, NY). The sequence of the new probe was determined using the BLAST program (Genetics Computer Group, Madison, WI) in order to maximize specificity by including sequences found in human SERT and to exclude sequences that are in common with the dopamine and norepinephrine transporters. The specificity of the probe was verified by the proper localization of SERT mRNA (intense labeling in the raphe nuclei and no labeling in the locus coeruleus). RNase-treated tissue showed no labeling. The probe was labeled with $\left[{ }^{35} \mathrm{~S}\right] \mathrm{dATP}$ (NEN, Boston, MA) using terminal deoxynucleotidyl transferase (Pharmacia Bio- 

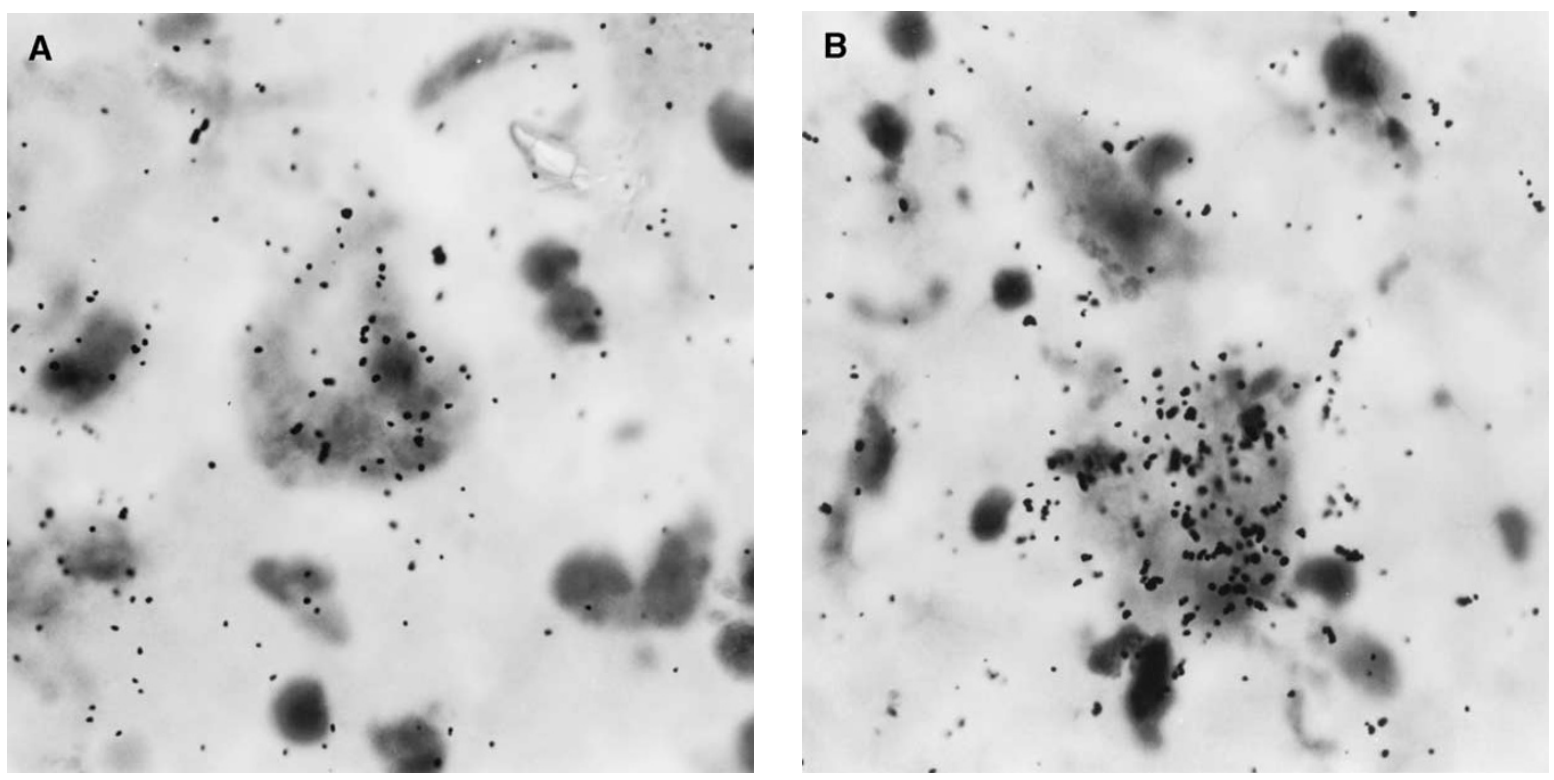

Figure 2. Hybridized tissue sections were dipped in photographic emulsion and analyzed for grain counting under a light microscope (silver grains represent SERT mRNA molecules). The expression of SERT mRNA in a representative control (A) and suicide (B). In controls, there are more positive neurons expressing the gene, but with less expression average per neuron than in suicides. Suicide victims (2B) have neurons with higher SERT mRNA grain density than controls and the nonexpressing neurons have a smaller soma area than expressing neurons.

tech, Piscataway, NJ) and purified by Bio-spin 6 column (Bio-Rad, Hercules, CA).

The assays were run in matched pairs to allow comparisons without having to take into account the variability in specific activity of the labeled probe. Sections were thawed and fixed in $4 \%$ formaldehyde for $5 \mathrm{~min}$, rinsed twice in PBS, and acetylated with $0.25 \%$ acetic anhydride in $0.1 \mathrm{M}$ triethanolamine, $\mathrm{pH} 8.0$ for $10 \mathrm{~min}$. Tissue was dehydrated and delipidated in a graded series of ethanol washes and chloroform. The in situ hybridization procedure (Austin et al. 1994; Young 1989) with minor modifications was carried out as follows. Tissue sections were prehybridized at $37^{\circ} \mathrm{C}$ for $2 \mathrm{~h}$ in a mixture containing $50 \%$ formamide, $600 \mathrm{mM} \mathrm{NaCl}, 80$ $\mathrm{mM}$ Tris- $\mathrm{HCl}$ (pH 7.5), $4 \mathrm{mM}$ EDTA, $0.1 \%(\mathrm{wt} / \mathrm{v})$ tetrasodium pyrophosphate, $0.2 \%(\mathrm{wt} / \mathrm{v})$ SDS, $0.2 \mathrm{mg} / \mathrm{ml}$ heparin sulfate, $10 \%(\mathrm{wt} / \mathrm{v})$ dextran sulfate, $10 \mathrm{mM}$ dithiothreitol, and $50 \mu \mathrm{M}$ dATP. Hybridization buffer has the same composition as the prehybridization buffer, but cold dATP is replaced with $1-2 \times 10^{6} \mathrm{cpm} /$ section of ${ }^{35}$ S-labeled probe.

Probe was added to each tissue section and a Parafilm coverslip was placed over the tissue. An additional control section was pretreated with RNase $(200 \mathrm{ng} / \mathrm{ml})$ in PBS for $30 \mathrm{~min}$ at room temperature. Sections were hybridized at $37^{\circ} \mathrm{C}$ for $17-20 \mathrm{~h}$, washed twice for $30 \mathrm{~min}$ each with $2 \times$ SSC $(1 \times$ SSC $=0.15 \mathrm{M}$ sodium chloride, $0.015 \mathrm{M}$ sodium citrate, $\mathrm{pH} 7.2$ ) and $50 \%$ formamide at $40^{\circ} \mathrm{C}$, followed by two 45 -min washes in $1 \times$ SSC at $40^{\circ} \mathrm{C}$. Slides were rinsed in distilled water, then dehydrated in $70 \%$ and $100 \%$ ethanol, dried, and exposed to Kodak Biomax MR x-ray film for two weeks. The films were developed with D-19 (Eastman Kodak, Rochester, $\mathrm{NY}$ ) for $4 \mathrm{~min}$ at $16^{\circ} \mathrm{C}$, rinsed briefly, and fixed (Kodak Rapid Fixer) for $10 \mathrm{~min}$. After developing, the slides were dipped into photographic emulsion (Kodak NTB2) diluted 1:1 with distilled water, exposed for three days at $4^{\circ} \mathrm{C}$, developed in Kodak D19, fixed, delipidated, and stained with $\mathrm{H} \& \mathrm{E}$.

\section{Densitometry of Receptor and In Situ Hybridization Autoradiograms}

Receptor autoradiograms were quantified using a computer-based image analysis system (MCID; Imaging Research, Inc.). After establishing shade correction, images of $\left[{ }^{3} \mathrm{H}\right]$ standards (American Radiolabeled Chemicals) were calibrated to femptomoles of radioligand per milligram of tissue (Geary et al. 1985). Calibrated images of total binding and nonspecific binding were aligned on separate channels and subtracted to produce an image of specific binding. Areas of interest were outlined on the image of specific binding. To reduce variability, each film contained sections from one matched pair.

For the semi-quantitation of in situ hybridization autoradiograms, the amount of mRNA was measured by the amount of radioactivity. The amount of radioactivity and its relationship to optical density was deter- 
mined using ${ }^{14} \mathrm{C}$ standard slides co-exposed with the tissue sections. The mRNA probes were labeled with ${ }^{35} \mathrm{~S}$. A linear relationship (with slope approximately equal to 1) between ${ }^{14} \mathrm{C}$ and ${ }^{35} \mathrm{~S}$ exists for the estimation of the amount of radioactivity determined autoradiographically. Therefore, ${ }^{14} \mathrm{C}$ standards can be used for measurement of the amount radioactivity of the ${ }^{35} \mathrm{~S}$ labeled probe (Miller 1991). We measured density in the adjacent central gray to obtain a ratio between the structures, thus allowing further semi-quantitative comparisons between groups. Three samples of the background were averaged and subtracted from the regions measured. The DRN sections were measured approximately every millimeter throughout the length of the nucleus.

The DRN (and MRN) are enriched with SERT sites. In addition, SERT sites are located on serotonergic axon terminals and along serotonergic axons in nearby regions innervated by these neurons. Hence, SERT binding in the area of the raphe extend well beyond the location of 5-HT cell bodies. Adjacent sections stained for Nissl substance with thionin and $\left[{ }^{3} \mathrm{H}\right] 8-\mathrm{OH}-\mathrm{DPAT}$ autoradiography were used to define the DRN, because we found a high degree of correspondence between sections from control subjects' immunostained for tryptophan hydroxylase (PH8) (Törk and Hornung 1990) and $\left[{ }^{3} \mathrm{H}\right] 8-\mathrm{OH}-\mathrm{DPAT}$ autoradiograms (Figures $1 \mathrm{~A}$ and 1B). It should, therefore, be noted that the volumes reported are the distribution volumes of $\left[{ }^{3} \mathrm{H}\right] 8-\mathrm{OH}-\mathrm{DPAT}$ binding. Binding capacity is introduced as a novel index of the total amount of receptors in the region of interest. Data expressed in this way resemble data reported from "regions of interest" in in vivo imaging studies.

\section{Binding Capacity}

Receptor binding or in situ hybridization experiments most typically produce data that reflect a concentration of receptors or mRNA in a region of interest (e.g., fmol of ligand binding/mg of tissue). The more physiologically relevant measure is arguably the total number of receptors. Determination of these numbers is logistically problematic because the region of interest is seldom specifically available or definable in its entirety (e.g., a specific Brodmann area) or anatomical specificity is more highly desirable (e.g., autoradiographic analysis of all brain regions contained in a brain section). Binding capacity is introduced as an index of the total number of receptors in a region of interest where: binding capacity $=$ receptor binding concentration $\times$ region volume. The amount of tissue is represented in each component of the product: (fmol/mg tissue) for receptor binding, $\mathrm{mm}^{3}$ for the region volume. These tissue amount measures can then be cancelled out leaving the product indexing fmol of labeled receptors. The binding capacity is not the true number of receptors. In autoradiography experiments using tritium as performed here, the radioactive quenching limits the radiolabel to the uppermost 3-5 $\mu \mathrm{m}$ of tissue (Rogers 1973). Furthermore, the relationship between fmol of ligand and the actual number of labeled receptors is not known.

\section{Grain Counting of In Situ Hybridization Data}

We counted the number of grains per neuron in the DRN. Cellular concentrations of mRNA from the emulsion autoradiograms were determined by digitizing the bright-field microscope image (Zeiss Universal) onto a computer screen via a video camera (Dage CCD-72). Neurons were considered positively labeled when the grain density was greater than five times the background density (e.g., Volk et al. 2000). The density of the background was measured in four different regions of the section: aqueduct, periaqueductal gray, pons, and in areas of DRN devoid of neurons. The mean of these four measurements was calculated and the value subtracted from neuron measurements. Positively labeled neurons were sampled by outlining the "cloud" of grains overlying the cell. Such sampling is subjective, but reliable (Chesselet and Weiss-Wunder 1994). Overlapping neurons were not sampled. Grain density over densely labeled cells was estimated (by the computer) by thresholding to optimize contrast and then dividing the total "target" area by the mean grain size.

A systematic random method of cell sampling was used. DRN tissue sections approximately $1 \mathrm{~mm}$ apart were sampled from each subject. The DRN area in cross-section was measured on the basis of $\left[{ }^{3} \mathrm{H}\right] 8-\mathrm{OH}-$ DPAT isodensity binding. We sampled from the total DRN area of each section by moving the microscope stage, so that we measured all the cells located in the spatially quantified upper right quadrant of the computer monitor, but not touching the right or upper margins of the sampling frame. We thus sampled one fourth of the DRN cells in the slides prepared for each subject. We measured for each neuron: area $\left(\mu \mathrm{m}^{2}\right)$, number of SERT mRNA grains per neuron, and grain density (number of grains per neuron $/ \mu \mathrm{m}^{2}$ ). The SERT mRNA grain density per neuron was corrected for background. The territory of the DRN and its subnuclei was defined using a camera lucida attachment to the microscope and the area determined using the pointgrid method. The boundaries of the DRN were identified at a magnification of 20X. The neurons were defined at a magnification of 200X. The number of grains overlying a neuron were determined a magnification of 500X. All sampling was done by personnel blind to the diagnosis of group assignment of the brain case.

\section{Statistical Analysis}

Paired sample $t$-tests were used for case-control pair wise comparisons of film autoradiography, $5-\mathrm{HT}_{1 \mathrm{~A}}$ 
binding area and volume in the DRN, positive neuron number, and neuron size. For independent samples, t-tests were used to compare film autoradiography, $5-\mathrm{HT}_{1 \mathrm{~A}}$ area and volume measures, and positive neuron number between males and females. Linear correlational analysis was used to analyze the relationship between film autoradiography and in situ hybridization measures and age and postmortem interval (PMI).

To examine the distribution of SERT mRNA grain density, the data were normalized by applying a square root function. Neurons were grouped according to their grain density into percentiles. The percentage of controls and suicides cells in each percentile was examined to determine the amount of SERT mRNA expression in the two groups and in males and females. All data are expressed as mean $\pm \mathrm{SD}$ and all $p$-values are 2-tailed.

\section{RESULTS}

\section{Analysis of Film-Based Autoradiograms}

Images of $\left[{ }^{3} \mathrm{H}\right] 8-\mathrm{OH}-\mathrm{DPAT}$ autoradiography were used to outline the boundaries of the DRN, because there is a high degree of correspondence between the outline of the DRN based on sections immunostained for trytophan hydroxylase (PH8) (Törk and Hornung 1990; Stockmeier et al. 1996) and the outline based on $\left[{ }^{3} \mathrm{H}\right] 8$ $\mathrm{OH}$-DPAT autoradiograms (Figures 1A and 1B).

The distribution volume of $5-\mathrm{HT}_{1 \mathrm{~A}}$ receptors in the DRN [total cross-sectional area $\left(\mathrm{mm}^{2}\right) \times$ the distance between sections $(\mathrm{mm})]$ as measured by the area of $\left[{ }^{3} \mathrm{H}\right] 8$ OH-DPAT autoreceptor binding, was $40 \%$ smaller in suicides compared with controls (C: $42.2 \pm 20.0$ vs. S: $25.3 \pm 13.7 \mathrm{~mm}^{3}, \mathrm{t}=3.47, \mathrm{df}=9, p=.007$ ) (Table 2). The volume of $5-\mathrm{HT}_{1 \mathrm{~A}}$ receptors in the MRN, similarly defined, was $23 \%$ less in suicides than controls (C: $27.5 \pm$ 10.7 vs. S: $\left.21.1 \pm 10.4 \mathrm{~mm}^{3}, \mathrm{t}=2.48, \mathrm{df}=9, p=.038\right)$.

\section{5-HT $1 \mathrm{~A}$ Receptors}

The concentration of $5-\mathrm{HT}_{1 \mathrm{~A}}$ receptors (fmol/mg tissue) in the DRN was not different in suicides compared with controls (C: $70.9 \pm 11.2$ vs. S: $63.4 \pm 15.3 ; p=.100)$. To estimate the total amount of binding in the DRN, we calculated an index of 5- $\mathrm{HT}_{1 \mathrm{~A}}$ receptor binding capacity (fmol/mg tissue $\times$ volume). In the DRN of suicide victims, the $5-\mathrm{HT}_{1 \mathrm{~A}}$ binding capacity was $43 \%$ lower than in controls (C: $3006.4 \pm 1516.3$ vs. S: $1703.6 \pm 1005.1, t=$ $3.82, \mathrm{df}=9, p=.004)$. The concentration of $5-\mathrm{HT}_{1 \mathrm{~A}}$ receptors (fmol/mg tissue) in the MRN was not significantly different between controls and suicides (Table 2). In the $\mathrm{MRN}$, the $5-\mathrm{HT}_{1 \mathrm{~A}}$ receptor binding capacity of suicide victims was $34 \%$ lower compared to controls (binding capacity: C: $1254.8 \pm 501.3$ vs. S: $824.7 \pm 489.2$, $\mathrm{t}=2.56, \mathrm{df}=9, p=.031$ ).

\section{Serotonin Transporter Sites (SERT)}

$\left[{ }^{3} \mathrm{H}\right]$ Cyanoimipramine SERT binding concentration (fmol/mg tissue; Figure 1C) in the DRN was not different in suicides and controls (C: $329.0 \pm 100.1$ vs. S: $358.1 \pm$ $160.1, p=.663)$. In the MRN SERT binding concentration was also not different in suicides vs. controls (Table 2).

\section{Serotonin Transporter mRNA}

In the DRN, SERT mRNA concentration $(\mu \mathrm{Ci} / \mathrm{g})$; Figure 1D, Table 2) was not different in suicides and controls. The concentration of SERT mRNA in the MRN did not differ between groups.

\section{Microscopic Analysis of SERT mRNA In Situ Hybridization}

There were 54\% fewer SERT mRNA expressing neurons (neurons that had grain density greater than five fold the

Table 2. Film Autoradiography and Microscopy Results for the DRN and the MRN of Matched Suicides and Controls

\begin{tabular}{|c|c|c|c|c|}
\hline & Controls (mean \pm SD) & Suicides (mean \pm SD) & $t$ & $p$ \\
\hline \multicolumn{5}{|l|}{ Dorsal raphe nucleus } \\
\hline Total cross-sectional area of $5-\mathrm{HT}_{1 \mathrm{~A}}$ binding in $\mathrm{DRN}\left(\mathrm{mm}^{2}\right)$ & $46.4 \pm 16.8$ & $24.6 \pm 11.2$ & 5.33 & .000 \\
\hline Volume of $5-\mathrm{HT}_{1 \mathrm{~A}}$ binding in $\mathrm{DRN}\left(\mathrm{mm}^{3}\right)$ & $42.2 \pm 20.0$ & $25.3 \pm 13.7$ & 3.47 & .007 \\
\hline$\left[{ }^{3} \mathrm{H}\right] 8-\mathrm{OH}-\mathrm{DPAT}$ binding (fmol/mg tissue) & $70.9 \pm 11.2$ & $63.4 \pm 15.3$ & 1.84 & .10 \\
\hline$\left[{ }^{3} \mathrm{H}\right]$ Cyanoimipramine binding ( $\mathrm{fmol} / \mathrm{mg}$ tissue) & $329.0 \pm 100.1$ & $358.1 \pm 160.1$ & -0.45 & .663 \\
\hline SERT mRNA amount ( $\mu \mathrm{Ci} / \mathrm{g}$ tissue) & $0.108 \pm 0.02$ & $0.106 \pm 0.04$ & 0.11 & .913 \\
\hline$\left[{ }^{3} \mathrm{H}\right] 8-\mathrm{OH}-\mathrm{DPAT}$ binding capacity $\left(\mathrm{fmol} / \mathrm{mg}\right.$ tissue $\left.\times \mathrm{mm}^{3}\right)$ & $3006.4 \pm 1516.3$ & $1703.6 \pm 1005.1$ & 3.82 & .004 \\
\hline Neuron area $\left(\mu \mathrm{m}^{2}\right)$ & $502.4 \pm 78.7$ & $590.6 \pm 93.7$ & -2.30 & .051 \\
\hline \multicolumn{5}{|l|}{ Median raphe nucleus } \\
\hline Total cross-sectional area $\left(\mathrm{mm}^{2}\right)$ & $24.6 \pm 10.3$ & $19.3 \pm 10.7$ & 1.29 & .230 \\
\hline MRN volume $\left(\mathrm{mm}^{3}\right)$ & $27.5 \pm 10.7$ & $21.1 \pm 10.4$ & 2.48 & .038 \\
\hline$\left[{ }^{3} \mathrm{H}\right] 8-\mathrm{OH}-\mathrm{DPAT}$ binding (fmol/mg tissue) & $46.3 \pm 7.4$ & $37.6 \pm 12.1$ & 1.94 & .085 \\
\hline$\left[{ }^{3} \mathrm{H}\right]$ Cyanoimipramine binding ( $\mathrm{fmol} / \mathrm{mg}$ tissue) & $200.4 \pm 52.5$ & $213.4 \pm 102.1$ & -0.36 & .728 \\
\hline SERT mRNA amount ( $\mu \mathrm{Ci} / \mathrm{g}$ tissue) & $0.08 \pm 0.01$ & $0.08 \pm 0.1$ & -0.32 & .758 \\
\hline$\left[{ }^{3} \mathrm{H}\right] 8-\mathrm{OH}-\mathrm{DPAT}$ binding capacity $\left(\mathrm{fmol} / \mathrm{mg}\right.$ tissue $\left.\times \mathrm{mm}^{3}\right)$ & $1254.8 \pm 501.3$ & $824.7 \pm 489.2$ & 2.56 & .031 \\
\hline
\end{tabular}


background density) observed in the DRN of suicide victims compared with normal controls (C: $7995 \pm 5186$ vs. $\mathrm{S}: 3705 \pm 2054, \mathrm{t}=2.45 \mathrm{df}=8, p=.040)$. We compared the characteristics of the neurons that did express the SERT gene in the two groups. The mean grain density per neuron (expressed as a ratio of neuron expression relative to the background) was not significantly different between suicides and controls (C: $9.00 \pm 5$ vs. S: $9.81 \pm 4$ ). Because there is a wide range of expression per neuron in both groups (C: min: 0-max: 42 vs. S: min: 0-max: 44), we compared the amount of SERT mRNA expressed, parsing grain density per neuron into percentiles (Figure 3). SERT mRNA expression per cell in the suicide group was skewed to the right compared with controls. In suicides, based on a median split, a higher percentage of neurons were in the upper percentiles compared to the control group $(\mathrm{t}=-2.33, \mathrm{df}=8, p=.048)$.

The mean neuronal area $\left(\mu \mathrm{m}^{2}\right)$ was not different between suicides and controls. There was a positive correlation between neuron area and grain density per neuron $(\mathrm{r}=0.183, p<.001)$. Neurons that did not express SERT mRNA had a smaller soma area than neurons that expressed SERT mRNA (area of non-expressing neurons $=467 \pm 90$, area of expressing neurons $=537 \pm$ $\left.107 \mu \mathrm{m}^{2}, \mathrm{t}=-2.456, \mathrm{df}=17, p=.025\right)$.

\section{Effect of pH, Age, Postmortem Interval (PMI), and Sex on Receptor Binding and SERT mRNA}

No effects of $\mathrm{pH}$ (range 6.23 to 6.77), age, sex, or PMI (time from death to collection of brain tissue) were observed on any of the film autoradiography measures for receptors or mRNA, or on the volume or area of the $5-\mathrm{HT}_{1 \mathrm{~A}}$ binding in the DRN and MRN. The number of SERT mRNA positive neurons did not correlate with age (data not shown). In suicides, the number of DRN neurons expressing SERT mRNA was lower than in controls throughout the age range of the sample (data not shown). There was no correlation between age and PMI (hours) and mean SERT mRNA grain density per cell, SERT mRNA positive neuron number, or density in either group.

There was no difference in the number of SERT mRNA positive neurons between males and females. Females had higher SERT mRNA grain density than males (males: $2.57 \pm 0.56$; females: $3.26 \pm 0.75, \mathrm{t}=$ $-2.23, \mathrm{df}=16, p=.04)$. Dividing the grain density per neuron into percentiles, the distribution in females is skewed to the right, and the percentage of cells belonging to the upper percentiles was higher than in males. This was present in all the subjects combined as well as separately in the suicide and the control groups $(\mathrm{C}: \mathrm{t}=$ $3.79, \mathrm{df}=6, p=.009 ; \mathrm{S}: \mathrm{t}=3.66, \mathrm{df}=6, p=.010)$.

\section{DISCUSSION}

We found no difference in SERT, SERT mRNA or 5-HT $1 \mathrm{~A}$ receptor binding concentration but a smaller $5-\mathrm{HT}_{1 \mathrm{~A}}$ receptor distribution volume and a smaller index of the total number of $5-\mathrm{HT}_{1 \mathrm{~A}}$ receptors in the DRN of suicide victims compared with controls. In the MRN, there was a decrease in total $5-\mathrm{HT}_{1 \mathrm{~A}}$ binding in suicides.

Total $5-\mathrm{HT}_{1 \mathrm{~A}}$ receptor binding in the DRN, designated as binding capacity of $\left[{ }^{3} \mathrm{H}\right] 8-\mathrm{OH}-\mathrm{DPAT}$, was $43 \%$ lower in suicides compared with controls, and in the MRN $\left[{ }^{3} \mathrm{H}\right] 8-\mathrm{OH}-\mathrm{DPAT}$ binding capacity was $34 \%$ lower in the suicides. Our results are consistent with the in vivo PET finding that $5 \mathrm{HT}_{1 \mathrm{~A}}$ receptor binding potential



Figure 3. Distribution of SERT mRNA expression in DRN neurons in controls and suicides. Neurons were grouped according to their grain density relative to background into percentiles. The percentage of cells from each control and suicide above or below the mean of all neurons was compared using a paired t-test. Note that suicides have a higher percentage of neurons with grain density in the upper percentiles compared to controls. Only SERT expressing DRN neurons are included. 
(using a $5-\mathrm{HT}_{1 \mathrm{~A}}$ antagonist) was reduced $42 \%$ in the raphe of depressed subjects with a family history of depression, compared to controls (Drevets et al. 1999). A recent postmortem study reported a $5-30 \%$ increase in $5-\mathrm{HT}_{1 \mathrm{~A}}$ receptor binding in the DRN of depressed suicides compared to controls (Stockmeier et al. 1998). That study examined the most rostral $2.5-5 \mathrm{~mm}$ of the DRN and did not analyze the total binding capacity in the DRN of both groups.

Consideration is needed in evaluating the volume of the DRN as determined by the volume of $5-\mathrm{HT}_{1 \mathrm{~A}}$ receptor distribution. First, the volume reported is based on the distribution of $\left[{ }^{3} \mathrm{H}\right] 8-\mathrm{OH}-\mathrm{DPAT}$ binding, and not the distribution of serotonin-synthesizing neurons labeled using immunocytochemistry directed towards tryptophan hydroxylase, as we have reported previously (Underwood et al. 1999). Using an antibody labeling tryptophan hydroxylase to define serotonin-synthesizing neurons, we previously (Underwood et al. 1999) found no difference in the volume of the DRN between depressed suicides and controls. The difference between the DRN volume from serotonin synthesizing neurons and the volume of $5-\mathrm{HT}_{1 \mathrm{~A}}$ receptors may be more than semantic.

The assay for $\left[{ }^{3} \mathrm{H}\right] 8-\mathrm{OH}-\mathrm{DPAT}$ is performed under conditions where the autoradiograms produced are optimized for total binding so that the images are not "saturated" due to binding in high concentration. The conditions we used previously in the immunocytochemistry study used assay conditions optimized (e.g., long incubations) for complete labeling of neurons and their processes. It is therefore likely that the two samples of volume will be different. For example, a boundary drawn to encompass a few scattered neurons in the caudal DRN might be a considerable area, whereas those few scattered neurons might not have enough $5-\mathrm{HT}_{1 \mathrm{~A}}$ receptors to produce an autoradiographic image significantly above background and producing no measurable DRN area.

Because the binding capacity is dependent on the tissue volume, it is important to consider the possibility of group differences due to a difference in the size of the DRN rather than to the number of 5-HT receptors per se. The DRN was complete or near complete in the majority of cases in both groups, and a comparable number of sections were sampled from each group. To further examine the possibility that the findings might be due to difference in partial or incomplete DRNs in the two groups, the analysis was re-done using cases with only complete DRN and similar results were obtained. We, therefore, do not believe that partial volumes can account for the reported differences. We did not estimate the volume of the DRN using autoradiograms from the in situ experiments because of the grainy appearance with irregular borders, or from the serotonin transporter distribution which is more widespread, located on terminals and not restricted to the DRN.
We found no difference in the concentration of $\left[{ }^{3} \mathrm{H}\right]$ Cyanoimipramine binding in the DRN of suicides compared to controls. This result is consistent with a report that $\left[{ }^{3} \mathrm{H}\right]$ paroxetine binding concentration to the SERT was not altered in the midbrain of depressed suicide victims (Bligh-Glover et al. 2000). It is intriguing to consider the notion of applying the reduced $5-\mathrm{HT}_{1 \mathrm{~A}}$ binding distribution volume in the raphe to the measures of serotonin transporter sites and message. If the "volume" of binding were multiplied by the SERT binding, we would find a reduction in SERT binding capacity in the DRN, but not the MRN of depressed suicides. This result would be consistent with the in vivo findings of Malison et al. (1998), who reported less brainstem SERT binding in patients with major depression using SPECT imaging of $\left[{ }^{123} \mathrm{I}\right] \beta$-CIT. Further work is needed to establish whether there is an alteration in SERT binding capacity or in the number of receptors per cell.

We found fewer SERT mRNA expressing neurons in the DRN of depressed suicides compared to controls. Within individual sections of tissue, SERT mRNA per $\mathrm{mg}$ tissue in the DRN did not differ between suicides and controls. A similar result was reported by Little et al. (1997) in that the SERT mRNA levels in specific levels of the dorsal and median raphe nuclei were not different between controls and depressed suicides. However, our microscopic analysis of SERT mRNA in situ hybridization revealed that fewer DRN neurons express the SERT mRNA in suicide victims Remarkably, in the subpopulation of serotonergic neurons that did express the serotonin transporter gene within the suicide group, there was evidence of elevated expression relative to the controls.

We found that DRN neurons that expressed SERT mRNA had a larger soma area than neurons that did not expressed SERT mRNA. In rodents, reserpine administration results in increased tyrosine hydroxylase mRNA in the locus coeruleus as well as increased neuronal size (Austin et al. 1990), through an unknown mechanism. Little is known as to what factors regulate neuron volume but there is some common effect that encompasses biosynthetic enzyme level and SERT gene expression.

We previously reported that suicides do not have fewer, but more, tryptophan hydroxylase containing neurons in the DRN compared to controls (Underwood et al. 1999) raising the question of the difference in the numbers of neurons estimated for SERT mRNA containing and tryptophan hydroxylase neurons if both SERT mRNA and tryptophan hydroxylase are located in the same neurons. We cannot know the actual reason from the studies we performed because the studies performed did not set out to determine the total number of neurons. Differences between the two studies that might explain the difference in number may be due to 
the different aims of the two studies. To estimate the number of tryptophan hydroxylase neurons, we used long incubations in the primary antibody to produce labeling of neurons and fibers. To estimate the number of grains associated with mRNA we limited the exposure to prevent saturating conditions where the number of grains would be more difficult to determine. Different experiment conditions could clearly result in labeling different number of neurons. Mechanistically, the biosynthetic enzyme tryptophan hydroxylase and the mRNA for the SERT are functionally related, yet distinct. One possibility is that increasing the amount of the biosynthetic enzyme, reducing the amount of SERT mRNA, and reducing the amount of $5-\mathrm{HT}_{1 \mathrm{~A}}$ inhibitory autoreceptors are homeostatic mechanisms consistent with our overall hypothesis of a serotonergic deficit.

There are two possible interpretations of these results. The first is that reduced serotonergic function or release, as suggested by reports of less serotonin and/ or 5-HIAA in the brainstem of suicide victims (Mann et al. 1986) and lower CSF 5-HIAA in the CSF of suicide attempters (Åsberg, 1997) and depressed patients (Åsberg et al. 1984; Mann et al. 1996) leads to a compensatory reduction in expression of the gene for the serotonin transporter, resulting in fewer transporter sites and an amplification of the effect of serotonin release by reduced reuptake. According to that model, the cells that are over-expressing the gene, are failing to exhibit this homeostatic mechanism. In that regard, fewer $5-\mathrm{HT}_{1 \mathrm{~A}}$ inhibitory autoreceptors would also serve to amplify the serotonin signal and be consistent with a homeostatic response. An alternative explanation is that the failure of expression of the transporter gene represents a broader failure of expression of key serotonergic genes, related to the dysfunction in the serotonin system that underlies the predisposition to suicidal behavior or to mood disorders. Future studies should examine the regulation of gene expression of other genes in the serotonergic neurons and whether there is a more general impairment of expression of serotonin-related genes. Separate analysis of suicide victims without a major depressive episode and depressed patients dying from causes other than suicide is required to determine whether the observed effects are associated with depression or suicide.

We examined the effect of demographic variables and of PMI on SERT and 5- $\mathrm{HT}_{1 \mathrm{~A}}$ receptor autoradiography and mRNA in situ hybridization, finding no influence on film receptor binding and mRNA measures. In the microscopic analysis we observed no mean differences in SERT expressing neuron number between males and females, but there was a greater variance in cell number in females compared to males. Moreover, there were a higher percentage of neurons with high expression of SERT mRNA in the female group. An enhancement of SERT expression by estrogen reported in rodents (McQueen et al. 1999a,b) may explain our finding. It is of note that the age range of the females in our sample was from 26 to 40 years old. Since those subjects are pre-menopausal, the variability of estrogen levels could explain the higher variance in the number of neurons expressing the SERT mRNA.

We have previously ruled out the possibility that the serotonergic deficiency is due to fewer serotonin synthesizing neurons in the dorsal raphe nucleus (DRN) where we found not fewer, but more, 5-HT neurons in the DRN of suicides (Underwood et al. 1999). If we assume that there are more serotonin neurons in the DRN of depressed suicides (Underwood et al. 1999), taken together with our finding of lower levels of expression and receptors, the reduction per neuron will be even more striking. Future studies should examine receptors per neuron in order to more precisely estimate changes in receptor binding at the level of neural transmission.

There are several potential confounding effects that need to be considered. One is the action of psychotropic drugs, particularly antidepressants, antemortem. Our study, and at least two other studies of serotonin transporter binding (Gross-Isseroff et al. 1989; Lawrence et al. 1990) excluded cases with known immediate antemortem antidepressant use. Human platelet and rodent studies disagree as to whether tricyclic antidepressants or selective serotonin reuptake inhibitors alter transporter binding after chronic administration (Owens and Nemeroff 1994; Benmansour et al. 1999). Nemeroff et al. (1994) found that platelet SERT binding was reduced in never-medicated depressed patients, evidence that past medication does not explain these results. A recent PET brain imaging study, using an antagonist, reported that major depressive disorder is associated with a widespread reduction in $5-\mathrm{HT}_{1 \mathrm{~A}}$ receptor binding that, in most regions, was not changed by selective serotonin reuptake inhibitor treatment (Sargent et al. 2000). Depressed individuals had lower raphe $5-\mathrm{HT}_{1 \mathrm{~A}}$ binding after a course of SSRIs. At this point, although improbable, it is not possible to totally rule out enduring effects of previous courses of antidepressants.

\section{CONCLUSIONS}

We found significant alterations in $5-\mathrm{HT}_{1 \mathrm{~A}}$ binding and SERT expression in the DRN in depressed suicides. One explanation is homeostatic changes to enhance the action of serotonin neurons. Given the serious psychopathology and receptor alterations in the prefrontal cortex and the reduced 5-HIAA in the CSF in depressed suicidal individuals and depressed suicides, it appears that the alterations in the DRN serotonin neurons do not adequately compensate for low serotonin release and turnover. 


\section{ACKNOWLEDGMENTS}

This work was supported by NIH grants MH40210 and MH46745. We are grateful to Dr. Steve P. Ellis for statistical advice and to the following individuals for helping with various aspects of the project: Mihran J. Bakalian, Virginia L. Johnson, Christopher Dye, Kevin C. Brennan, and Victor V. Arkhipov.

\section{REFERENCES}

Arango V, Underwood MD, Gubbi AV, Mann JJ (1995): Localized alterations in pre- and postsynaptic serotonin binding sites in the ventrolateral prefrontal cortex of suicide victims. Brain Res 688:121-133

Åsberg M (1997): Neurotransmitters and suicidal behavior. The evidence from cerebrospinal fluid studies. Ann N Y Acad Sci 836:158-181

Åsberg M, Bertilsson L, Martensson B, Scalia Tomba GP, Thorén P, Träskman-Bendz L (1984): CSF monoamine metabolites in melancholia. Acta Psychiatr Scand 69: 201-219

Austin MC, Bradley CC, Mann JJ, Blakely RD (1994): Expression of serotonin transporter messenger RNA in the human brain. J Neurochem 62:2362-2367

Austin MC, Cottingham SL, Paul SM, Crawley JN (1990): Tyrosine hydroxylase and galanin mRNA levels in locus coeruleus neurons are increased following reserpine administration. Synapse 6:351-357

Benmansour S, Cecchi M, Morilak DA, Gerhardt GA, Javors MA, Gould GG, Frazer A (1999): Effects of chronic antidepressant treatments on serotonin transporter function, density, and mRNA level. J Neurosci 19:1049410501

Bligh-Glover W, Kolli TN, Shapiro-Kulnane L, Dilley GE, Friedman L, Balraj E, Rajkowska G, Stockmeier CA (2000): The serotonin transporter in the midbrain of suicide victims with major depression. Biol Psychiatry 47:1015-1024

Bobillier P, Petitjean F, Salvert D, Ligier M, Seguin S (1975): Differential projections of the nucleus raphe dorsalis and nucleus raphe centralis as revealed by autoradiography. Brain Res 85:205-210

Bobillier P, Seguin S, Petitjean F, Salvert D, Touret M, Jouvet M (1976): The raphe nuclei of the cat brain stem: A topographical atlas of their efferent projections as revealed by autoradiography. Brain Res 113:449-486

Chesselet M-F, Weiss-Wunder LT (1994): Quantification of in situ hybridization histochemistry. In Eberwine $\mathrm{JH}$, Valentino KL, Barchas JD (eds), In Situ Hybridization in Neurobiology: Advances in Methodology. New York, Oxford University Press, pp 114-123

Coccaro EF, Siever LJ, Klar HM, Maurer G, Cochrane K, Cooper TB, Mohs RC, Davis KL (1989): Serotonergic studies in patients with affective and personality disorders. Correlates with suicidal and impulsive aggressive behavior. Arch Gen Psychiatry 46:587-599

Damasio H, Grabowski T, Frank R, Galaburda AM, Damasio AR (1994): The return of Phineas Gage: Clues about the brain from the skull of a famous patient. Science 264:1102-1105

Drevets WC, Frank E, Price JC, Kupfer DJ, Holt D, Greer PJ, Huang Y, Gautier C, Mathis C (1999): PET imaging of serotonin 1A receptor binding in depression. Biol Psychiatry 46:1375-1387

Geary WAII, Toga AW, Wooten GF (1985): Quantitative film autoradiography for tritium: Methodological considerations. Brain Res 337:99-108

Gross-Isseroff R, Israeli M, Biegon A (1989): Autoradiographic analysis of tritiated imipramine binding in the human brain post mortem: Effects of suicide. Arch Gen Psychiatry 46:237-241

Harrison PJ, Heath PR, Eastwood SL, Burnet PWJ, McDonald B, Pearson RCA (1995): The relative importance of premortem acidosis and postmortem interval for human brain gene expression studies: Selective mRNA vulnerability and comparison with their encoded proteins. Neurosci Lett 200:151-154

Isometsä E, Henriksson M, Heikkinen M, Aro H, Lönnqvist J (1994): Suicide and the use of antidepressants. Drug treatment of depression is inadequate. BMJ 308:915

Kassir SA, Underwood MD, Bakalian MJ, Mann JJ, Arango V (1998): $5-\mathrm{HT}_{1 \mathrm{~A}}$ binding in dorsal and median raphe nuclei of suicide victims. Soc Neurosci Abstr 24:1274

Kelly TM, Mann JJ (1996): Validity of DSM-III-R diagnosis by psychological autopsy: A comparison with antemortem diagnosis. Acta Psychiatr Scand 94:337-343

Lawrence KM, De Paermentier F, Cheetham SC, Crompton MR, Katona CLE, Horton RW (1990): Brain 5-HT uptake sites, labelled with $\left[{ }^{3} \mathrm{H}\right]$ paroxetine, in antidepressantfree depressed suicides. Brain Res 526:17-22

Lesch KP, Aulakh CS, Wolozin BL, Tolliver TJ, Hill JL, Murphy DL (1993): Regional brain expression of serotonin transporter mRNA and its regulation by reuptake inhibiting antidepressants. Mol Brain Res 17:31-35

Little KY, McLauglin DP, Ranc J, Gilmore J, Lopez JF, Watson SJ, Carroll FI, Butts JD (1997): Serotonin transporter binding sites and mRNA levels in depressed persons committing suicide. Biol Psychiatry 41:1156-1164

Malison RT, Price LH, Berman R, Van Dyck CH, Pelton GH, Carpenter L, Sanacora G, Owens MJ, Nemeroff CB, Rajeevan N, Baldwin RM, Seibyl JP, Innis RB, Charney DS (1998): Reduced brain serotonin transporter availability in major depression as measured by [ $\left.{ }^{123} \mathrm{I}\right]-2 \beta$-carbomethoxy$3 \beta$-(4-iodophenyl)tropane and single photon emission computer tomography. Biol Psychiatry 44:1090-1098

Malone KM, Corbitt EM, Li S, Mann JJ (1996): Prolactin response to fenfluramine and suicide attempt lethality in major depression. Br J Psychiatry 168:324-329

Malone KM, Placidi GPA, Oquendo MA, Campbell C, Cooper TB, Van Heertum R, Mann JJ (2000): Frontal cortex serotonin-related hypofunction visualized by PET in high-lethality suicide attempters with major depression compared to low lethality. Soc Neurosci Abstr 26:2086

Mann JJ, Arango V, Marzuk PM, Theccanat S, Reis DJ (1989): Evidence for the 5-HT hypothesis of suicide: A review of post-mortem studies. Br J Psychiatry 155 (Suppl 8):7-14

Mann JJ, Huang Y, Underwood MD, Kassir SA, Oppenheim S, Kelly TM, Dwork AJ, Arango V (2000): A serotonin 
transporter gene promoter polymorphism (5-HTTLPR) and prefrontal cortical binding in major depression and suicide. Arch Gen Psychiatry 57:729-738

Mann JJ, Malone KM (1997): Cerebrospinal fluid amines and higher lethality suicide attempts in depressed inpatients. Biol Psychiatry 41:162-171

Mann JJ, Malone KM, Diehl DJ, Perel J, Cooper TB, Mintun MA (1996): Demonstration in vivo of reduced serotonin responsivity in the brain of untreated depressed patients. Am J Psychiatry 153:174-182

Mann JJ, McBride PA, Malone KM, DeMeo MD, Keilp JG (1995): Blunted serotonergic responsivity in depressed patients. Neuropsychopharmacology 13:53-64

Mann JJ, McBride PA, Stanley M (1986): Postmortem monoamine receptor and enzyme studies in suicide. Ann N Y Acad Sci 487:114-121

McQueen JK, Wilson H, Fink G (1999a): Estradiol-17 $\beta$ increases serotonin transporter (SERT) mRNA levels and the density of SERT-binding sites in female rat brain. Mol Brain Res 45:13-23

McQueen JK, Wilson H, Sumner BEH, Fink G (1999b): Serotonin transporter (SERT) mRNA and binding site densities in male rat brain affected by sex steroids. Mol Brain Res 63:241-247

Middlemiss DN, Fozard JR (1983): 8-hydroxy-2-(di-n-propylamino)-tetralin discriminates between subtypes of the 5- $\mathrm{HT}_{1}$ recognition site. Eur J Pharmacol 90:151-153

Miller JA (1991): The calibration of ${ }^{35} \mathrm{~S}$ or ${ }^{32} \mathrm{P}$ with ${ }^{14} \mathrm{C}$-labeled brain paste or ${ }^{14} \mathrm{C}$-plastic standards for quantitative autoradiography using LKB Ultrofilm or Amersham Hyperfilm. Neurosci Lett 121:211-214

Nemeroff CB, Knight DL, Franks J, Craighead WE, Krishnan KRR (1994): Further studies on platelet serotonin transporter binding in depression. Am J Psychiatry 151:16231625

Owens MJ, Nemeroff CB (1994): Role of serotonin in the pathophysiology of depression: Focus on the serotonin transporter. Clin Chem 40:288-295

Perry EK, Marshall EF, Blessed G, Tomlinson BE, Perry RH (1983): Decreased imipramine binding in the brains of patients with depressive illness. Br J Psychiatry 142: 188-192

Rogers AW (1973): Techniques of Autoradiography. London, Elsevier Scientific Publishing Company

Sakai K, Salvert D, Touret M, Jouvet M (1977): Afferent connections of the nucleus raphe dorsalis in the cat as visualized by the horseradish peroxidase technique. Brain Res 137:11-35

Sargent PA, Kjaer KH, Bench CJ, Robiner EA, Messa C, Meyer J, Gunn RN, Grasby PM, Cowen PJ (2000): Brain serotonin $_{1 \mathrm{~A}}$ receptor binding measured by Positron Emission Tomography with $\left[{ }^{11} \mathrm{C}\right] W A Y-100635$. Effects of depression and antidepressant treatment. Arch Gen Psychiatry 57:174-180

Stanley B, Molcho A, Stanley M, Winchel R, Gameroff MJ, Parsons B, Mann JJ (2000): Association of aggressive behavior with altered serotonergic function in patients who are not suicidal. Am J Psychiatry 157:609-614

Stockmeier CA, Shapiro LA, Dilley GE, Kolli TM, Friedman L, Rajkowska G (1998): Increase in serotonin-1A autoreceptors in the midbrain of suicide victims with major depression - postmortem evidence for decrease serotonin activity. J Neurosci 18:7394-7401

Stockmeier CA, Shapiro LA, Haycock JW, Thompson PA, Lowy MT (1996): Quantitative subregional distribution of serotonin $\mathrm{in}_{\mathrm{A}}$ receptors and serotonin transporters in the human dorsal raphe. Brain Res 727:1-12

Törk I, Hornung J-P (1990): Raphe nuclei and the serotonergic system. In Paxinos G (ed), The Human Nervous System. San Diego, Academic Press, pp 1001-1022

Underwood MD, Khaibulina AA, Ellis SP, Moran A, Rice PM, Mann JJ, Arango V (1999): Morphometry of the dorsal raphe nucleus serotonergic neurons in suicide victims. Biol Psychiatry 46:473-483

Vergé D, Daval G, Patey A, Gozlan H, Mestikawy SE, Hamon M (1985): Presynaptic 5-HT autoreceptors on serotonergic cell bodies and/or dendrites but not terminals are of the 5- $\mathrm{HT}_{1 \mathrm{~A}}$ subtype. Eur J Pharmacol 113: 463-464

Volk DW, Austin MC, Pierri JN, Sampson AR, Lewis DA (2000): Decreased glutamic acid decarboxylase ${ }_{67}$ messenger RNA expression in a subset of prefrontal cortical g-aminobutyric acid neurons in subjects with schizophrenia. Arch Gen Psychiatry 57:237-245

Wang RY, Aghajanian GK (1977): Antidromically identified serotonergic neurons in the rat midbrain raphe: Evidence for collateral inhibition. Brain Res 132:186-193

Willeit M, Praschak-Rieder N, Neumeister A, Pirker W, Asenbaum S, Vitouch O, Tauscher J, Hilger E, Stastny J, Brucke T, Kasper S (2000): [123I]-beta-CIT SPECT imaging shows reduced brain serotonin transporter availability in drug-free depressed patients with seasonal affective disorder. Biol Psychiatry 47:482-489

Wilson MA, Molliver ME (1991a): The organization of serotonergic projections to cerebral cortex in primates: Regional distribution of axon terminals. Neuroscience 44:537-553

Wilson MA, Molliver ME (1991b): The organization of serotonergic projections to cerebral cortex in primates: Retrograde transport studies. Neuroscience 44:555-570

Young WS III (1989): In situ hybridization histochemical detection of neuropeptide mRNA using DNA and RNA probes. Methods Enzymol 168:702-710 